\title{
Systemic rosiglitazone administration leads to cementocytes apoptosis in wild type mice
}

A administração sistêmica de rosiglitazona leva à apoptose de cementócitos em camundongos

\author{
R. A. B. da Silva'; L. A. B. da Silva'; K. M. H. de Oliveira-Vanderlei²; R. \\ Barbosa-Lima $^{1 *}$; A. Consolaro ${ }^{3}$ \\ ${ }^{1}$ Department of Pediatric Dentistry, School of Dentistry of Ribeirão Preto, University of São Paulo, 14040-904, \\ Ribeirão Preto-SP, Brazil \\ ${ }^{2}$ Department of Dentistry of Lagarto, Federal University of Sergipe, 49400-000, Lagarto-SE, Brazil \\ ${ }^{3}$ Department of Oral Pathology, Bauru Dental School, University of São Paulo, 17012-901, Bauru-SP, Brazil \\ *ricardobarbosalima@usp.br \\ (Recebido em 13 de outubro de 2020; aceito em 09 de julho de 2021)
}

\begin{abstract}
It has been shown that a class of drugs for diabetes control, the thiazolidinediones, leads to increased apoptosis in osteocytes. Considering the correlations between osteocytes and cementocytes, the aim of this study was to demonstrate the apoptosis on cementocytes of wild type mice that had received rosiglitazone. Twenty-four male C57BL/6 mice were divided into 3 groups: 1 control, which received only the vehicle administration via oral for 1 week (PBS+DMSO 10\%) and other two groups, which received $10 \mathrm{mg} / \mathrm{kg}$ of RGZ+PBS+DMSO $10 \%$ for 1 or 2 weeks, respectively. Upon completion of the time courses, mice were killed by $\mathrm{CO}_{2}$ and the mandibles were dissected and subjected to routine histotechnical processing. The sections were analyzed through transferase-mediated dUTP nick-end labeling (TUNEL) and 4',6- diamidino2-phenylindole (DAPI) staining of nuclear morphology $(\alpha=0.05)$. Control group showed significantly lower apoptotic cells/total cells ratio when compared to the experimental groups with TUNEL and DAPI methods ( $\mathrm{p}=0.010$ and 0.004 , respectively). TUNEL method showed approximately 20\% TUNEL-positive cementocytes in control and $26 \%$ in both experimental groups, while the DAPI technique showed approximately $32 \%$ of DAPI-positive cementocytes in control and $38 \%$ to $40 \%$ in experimental groups. The rosiglitazone systemic administration can lead to cementocytes apoptosis in mice. Despite the differences between the experimental and control groups, the death of cementocytes occurred as a physiological phenomenon, important in understanding the role of these cells in periodontal tissue.
\end{abstract}

Keywords: dental cementum, DAPI, in situ nick-end labeling.

Foi demonstrado que uma classe de medicamentos para o controle do diabetes, as tiazolidinedionas, leva ao aumento da apoptose dos osteócitos. Considerando as correlações entre osteócitos e cementócitos, o objetivo deste estudo foi demonstrar a apoptose de cementócitos em camundongos selvagens que receberam rosiglitazona. Vinte e quatro camundongos C57BL / 6 machos foram divididos em 3 grupos: 1 controle, que recebeu apenas a administração do veículo via oral por 1 semana (PBS + DMSO 10\%) e outros dois grupos, que receberam $10 \mathrm{mg} / \mathrm{kg}$ de RGZ + PBS + DMSO $10 \%$ por 1 ou 2 semanas, respectivamente. Após a conclusão destes ciclos, os camundongos foram mortos por $\mathrm{CO}_{2}$ e as mandíbulas foram dissecadas e submetidas ao processamento histotécnico de rotina. As secções foram analisadas por meio de marcação dUTP nick-end mediada por transferase (TUNEL) e coloração 4',6-diamidino-2-fenilindol (DAPI) da morfologia nuclear $(\alpha=0,05)$. O grupo controle apresentou relação células apoptóticas/células totais significativamente menor quando comparado aos grupos experimentais pelos métodos TUNEL e DAPI ( $\mathrm{p}=0.010$ e 0.004 , respectivamente). O método TUNEL mostrou aproximadamente $20 \%$ de cementócitos TUNEL-positivos no controle e $26 \%$ em ambos os grupos experimentais, enquanto a técnica DAPI mostrou aproximadamente $32 \%$ de cementócitos DAPI-positivos no controle e $38 \%$ a $40 \%$ nos grupos experimentais. A administração sistêmica da rosiglitazona pode levar à apoptose dos cementócitos em camundongos. Apesar das diferenças entre os grupos experimental e controle, a morte dos cementócitos ocorreu como um fenômeno fisiológico, importante no entendimento do papel dessas células no tecido periodontal. Palavras-chave: cemento dentário, DAPI, marcação in situ das extremidades cortadas.

\section{INTRODUCTION}

The tooth root cementum is a mineralized, non-innervated and avascular tissue that covers the dentin. In addition to the mineral matrix, cementoblasts and cementocytes are the cell types present 
in this tissue. On the cervical root portion, the cementum is acellular, while it is cellular when covering the apical root. It is known that the acellular cementum provides critical influence on the attachment of the tooth to the surrounding periodontal ligament (PDL). The cementoblasts are located on the cementum surface, which covers the dental root surface, where the periodontal collagen fibers are attached. These cells protect the tooth root from bone turnover and resorptions since they do not present specific receptors for this phenomenon. During formation of cellular cementum, cementoblasts secrete the cementoid, an unmineralized extracellular matrix (ECM). During this process, some cementoblasts are embedded in the ECM and become cementocytes [1].

In general, the cementum is similar to bone. It is well known that during bone remodeling the osteocyte cell plays multifunctional roles by regulating both osteoblast and osteoclast function [2, 3]. Also, it is well described that osteocytes play an important role in the pathogenesis of bone diseases, such as osteoporosis and osteoarthritis $[4,5]$. Also, there are few evidence describing the role of these cells during oral processes and diseases $[6,7]$.

Although there are some similarities between osteocytes and cementocytes, differentiation and functions remains poorly understood [8-10]. The function of cementocytes in periodontal physiology was not well established. However, it is possible that this cell type presents a regulatory role in cementum. Therefore, the cementocyte could be such a dynamic actor in cementum metabolism as the osteocyte in the bone $[1,8]$.

Moreover, side effects on bone tissue cells have been reported after the use of a class of insulin sensitizing antidiabetic agents indicated for use in type 2 diabetes mellitus, the thiazolidinediones (TZD). The rosiglitazone (RGZ) belongs to this class of drugs, which are high-affinity synthetic agonists for peroxisome proliferator-activated receptor- $\gamma$ (PPAR- $\gamma)$. This receptor is involved in the osteoblast or adipocyte differentiation, a fact that could be related to the later differentiation of osteocytes [11-15]. We previously showed the significant effect of rosiglitazone-induced osteocytes apoptosis during periapical lesion development [16].

In Dentistry, Matsuzawa et al. showed the effect of cementocytes cell death during orthodontic tooth movement, but there are a lot to elucidate during oral diseases [17]. Also, until now, the effect of cementocytes apoptosis in the periapical lesion development was not studied.

The null hypothesis was that systemic administration of RGZ leads to cementocytes apoptosis in an experimental model. Therefore, the aim of this study was to demonstrate the occurrence of apoptosis in cementocytes of wild type mice that had received RGZ.

\section{MATERIALS AND METHODS}

Twenty-four male WT C57BL/6 mice, aged 6-8 weeks, with an average weight of 20 grams were used. The animals were obtained from the Central Animal Laboratory of University of São Paulo, Brazil, and kept in the Animal Laboratory of Ribeirão Preto School of Dentistry - USP, under a 12-h light/dark cycle, controlled temperature and humidity and free access to food and water. All animal procedures were carried out in accordance with the ethical guidelines of the Ethics Committee of the Campus of Ribeirão Preto of the University of São Paulo (Process 2014.1.450.58.8), supported by the National Council for Scientific and Technological Development (grant no 444604/2014-6).

After power analysis, to reach a statistically significant difference of apoptotic cells between the groups and to control the type I error under 0.05 with $80 \%$ of power, approximately seven mice should be needed per group, using one-way ANOVA. Therefore, eight animals per group (counting on possible surgical losses) were analyzed.

The twenty-four animals were simply randomized (by using a table of random numbers) and divided into three groups: 1 control, which received only the vehicle administration via oral for 1 week (PBS+DMSO 10\%) and other two groups, which received $10 \mathrm{mg} / \mathrm{kg}$ of RGZ+PBS+DMSO $10 \%$ for 1 or 2 weeks, respectively. The experimental unit used was the single animal.

Upon completion of the time courses, mice were killed by $\mathrm{CO}_{2}$. The mandibles were dissected and fixed in 10\% phosphate-buffered formalin for 16 hours at room temperature, washed in running water for 4 hours, and decalcified in $4.13 \%$ ethylenediaminetetraacetic acid (EDTA; pH=7.2) at room temperature for approximately 3 weeks. After, the samples were subjected to routine 
histotechnical processing. Longitudinal $5-\mu \mathrm{m}$-thick semi-serial sections were cut in a mesiodistal orientation using a Leica microtome [20,21].

The Terminal Deoxynucleotidyl Transferase-mediated Deoxyuridine Triphosphate Nick End Labeling Method (TUNEL) was used to detect DNA fragments derived from apoptotic cells. Dewaxed sections were stained with the Apop Tag-Plus Kit (Oncor, Gaithersburg, MD). The sections were pretreated in $20 \mu \mathrm{g} / \mathrm{ml}$ proteinase K (Oncor-Protein Digesting Enzyme) for $15 \mathrm{~min}$ at $37^{\circ} \mathrm{C}$, and after several washings in distilled water they were immersed in $3 \%$ hydrogen peroxide in PBS (50 mM sodium phosphate, $\mathrm{pH} 7.4,200 \mathrm{mM} \mathrm{NaCl}$ ) for $15 \mathrm{~min}$; they were then immersed in the equilibration buffer. After incubation in TdT enzyme (terminal deoxynucleotidyl transferase) at $37^{\circ} \mathrm{C}$ for $1 \mathrm{hr}$ in a humidified chamber, the reaction was stopped by immersion in a stop/wash buffer at $37^{\circ} \mathrm{C}$ for $15 \mathrm{~min}$.

Then, the sections were washed in PBS for $10 \mathrm{~min}$ and incubated in anti-digoxigenin-peroxidase at $37^{\circ} \mathrm{C}$ for 1 hour, in a humidified chamber. After several washings in PBS, the sections were treated with $0.06 \%$ 3.38-diaminobenzidine tetrahydrochloride (Sigma, St. Louis, MO) in the presence of $0.1 \%$ hydrogen peroxide for $5-10 \mathrm{~min}$, at room temperature. The sections were counterstained with hematoxylin, dehydrated in $100 \%$ butanol, rinsed in xylol and mounted in Entellan medium. Involuting mammary or prostate gland sections were used as positive controls for the TUNEL method. Negative controls were incubated in medium lacking TdT enzyme [20].

The 4',6-diamidino-2-phenylindole staining (DAPI) was used for DNA condensation examination. Briefly, dewaxed sections were washed with PBS tree times of five minutes each, waterproofed with $0.5 \%$ PBS-Triton, and washed again with PBS tree times of five minutes each. Then, they were incubated with DAPI $(1 \mu \mathrm{g} / 4 \mathrm{~mL})$ for approximately five minutes, at room temperature in the dark.

All analyses were performed under a conventional light microscopy (Carl Zeiss MicroImaging $\mathrm{GmbH}$, Göttingen, Germany). For the TUNEL analysis, no filter was used, whereas for correct visualization of DAPI stained sections, an appropriate microscopy filter was used. The apical cementum of the mesial and distal roots of the first and second mandibular molars from each animal were analyzed. For the cell counting and quantification of apoptotic cells, five to six random microscopic fields were analyzed (magnification 630x).

The ratio of apoptotic cells/total cells in each field was calculated using the Image $\mathbf{J}$ software (1.49u National Institutes of Health, USA). The ratios from two sections were then averaged for each animal and the values from all eight animals per group at each time point were used to conduct statistical tests [21]. TUNEL-positive cementocytes were considered when stained with brown color, presenting nuclei fragmentation (Figure 1A). DAPI-positive cementocytes were considered when their nuclei presented fluorescent defined spots, showing nucleus condensation (Figure 1B) [22-24].

Statistical analysis was carried out using Graph Pad Prism 4 (Graph Pad Software Inc., San Diego, CA, USA). A significance level of 5\% was set for all analyses. Once data presented a normal distribution after the Shapiro-Wilk test, one-way ANOVA and Bonferroni's post hoc test were used to compare the differences among means of cell counting ratios.

\section{RESULTS AND DISCUSSION}

The control group showed significantly lower apoptotic cells/total cells ratio, when compared to the experimental groups, in TUNEL and DAPI techniques ( $\mathrm{p}=0.01$ and $\mathrm{p}=0.004$, respectively). Slices stained by the TUNEL method showed approximately $20 \%(0.201 \pm 0.03)$ of Tunel-positive cementocytes in the control group, $26 \%(0.266 \pm 0.03)$ of TUNEL-positive cementocytes in the group that received one week of TZD administration, and 26\% (0.265 \pm 0.05$)$ of TUNEL-positive cementocytes in the group receiving two weeks of TZD administration ( $\mathrm{p}=0.01$ ) (Figure 2A). 




Figure 1. A: Red arrows show non-apoptotic cells, with sound nuclei and blue staining. Yellow arrows show apoptotic cells, with brown staining, seen by the TUNEL analysis. B: Red arrows show non-apoptotic cells, with sound nuclei (homogeneous fluorescent or without any fluorescence). Yellow arrows show condensed DNA areas at cell nuclei, seen by defined fluorescent spots, in apoptotic cells, by DAPI staining.

Evaluation by the DAPI technique showed approximately $32 \%(0.327 \pm 0.06)$ of DAPI-positive cementocytes in the control group, $38 \%(0.380 \pm 0.05)$ of DAPI-positive cementocytes in the oneweek TZD group, and $40 \%(0.407 \pm 0.03)$ of DAPI-positive cementocytes in the two-week TZD group $(\mathrm{p}=0.004)($ Figure 2B).
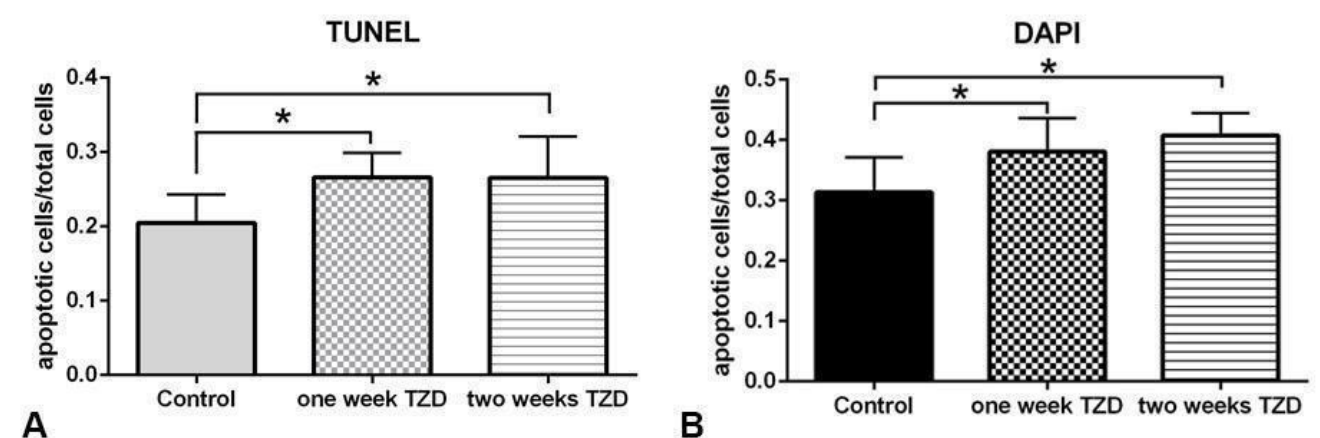

Figure 2. A: Apoptotic/total cells ratio obtained by TUNEL. B: Apoptotic/total cells ratio obtained by DAPI.

It is known that adipocytes and osteocytes are sourced from the same progenitor cell, changing their destinations depending on the activation. If by RUNX2, they follow a differentiation for osteoblasts lineage, while activation by PPAR- $\gamma$ leads to the development of adipocytes. The TZD are agonists of PPAR- $\gamma$ and it has been suggested that these drugs increase the differentiation of adipocytes at the expense of osteoblasts in vitro. Furthermore, the TZD have been reported to significantly increase the apoptosis of osteocytes and expression of sclerostin [14, 15, 25-27].

Despite differences between cementocytes and osteocytes, there are clearly important resemblances between them [1]. Thus, events that affect osteocytes could similarly be expressed in cementocytes, contributing to a better understanding of the latter. For this reason, after the increase in osteocyte apoptosis observed due to RGZ administration, our research group decided to investigate the cementocytes behavior under these conditions [27].

Apoptosis can be differentiated from necrosis by their characteristic nuclear changes. The TUNEL method is used for the detection of the DNA fragmentation characteristic of apoptosis, whereas DAPI is a nuclear stain which is observed as blue fluorescence when excited under fluorescence microscope, representing the nuclear condensation due to DNA fragmentation. However, TUNEL may give false positive results due to variations in labeling technique as well as staining of cells that have undergone non-apoptotic DNA strand breaks. Therefore, the extent of TUNEL is usually normalized to total nuclear content using DAPI staining [20, 23, 24, 28-30]. 
In the present study, all apoptotic cells were considered as cementocytes due to their morphology and tissue localization (within the lacunae in the apical cementum). By labeling the mandibles of wild type mice with RGZ, it was possible to observe that cementocytes presented apoptosis. In addition, all animals in the control group also presented apoptosis, evidencing the normality of this event. These events had never been previously described and are reported herein to present this finding to other investigators and promote a discussion about the function of these cells in periodontal physiology. It is prudent to highlight that, because of not addressing additional methods of cell identification in the present study, the number of apoptotic cementocytes may be slightly lower.

The apoptosis of bone cells is an essential phenomenon to the bone tissue, since it plays varied roles from endochondral ossification, leading to cartilage mineralization, until bone maturation, responsible for the release of angiogenic factors that stimulate vascular invasion and migration of osteoblasts and osteoclasts, which results in remodeling of calcified cartilage and formation of trabecular bone [31].

Moreover, the three-dimensional mechanosensory network of osteocytes controls the bone shape and volume. Via mediators released by the lacuno-canalicular system, they regulate the function of osteoblasts and osteoclasts in the inner and outer surfaces of structures. This formation/resorption phenomenon represents the core of physiological and metabolic control of bone and of the ionic balance in the body [2].

Recent evidence, added to our findings, also contributes to the understanding of the cementocyte as an active cell type in cementum physiology. A remodeling compartment in cementum was recently identified [32], as well as the in vitro responsiveness of cementocyte-like cells to inorganic phosphate has been described, demonstrating a potential role in the development of cementum [10].

Thus, cementocytes, through the determined three-dimensional network, might be the mechanism controlling the position and adaptation of root structures in the presence of several epigenetic functional factors to which teeth are submitted, such as occlusal load, orthodontic movement and others [17].

It is important to clarify that the evidence on TZDs indicates that this class of drugs can cause the reduction of insulin resistance as a primary effect of the activation of PPAR- $\gamma$ receptors in adipose tissue. However, the side effects of TZDs have limited their clinical use in the treatment of diabetes. One of the clinical concerns in the use of TZDs, including RGZ, is the risk of bone fractures. In experimental approaches, the use of this medication can lead to loss of bone mineral density due to increased events of osteoclastogenesis and reduced osteoblastogenesis [33, 34].

Considering the turnover of bone cells, osteocytes coordinate the resorption and formation of bone tissue by cytokines, including RANKL (kappa B nuclear activator receptor ligand) and sclerostin. However, the bone remodeling process is related to the behavior of osteoblastic cells in the presence of insulin. Therefore, when there is resistance to insulin, bone turnover can be reduced. The activation of PPAR- $\gamma$ by rosiglitazone can interfere in the differentiation of mesenchymal cells and lead to RANKL increase, supporting osteoclastic activity [34-36].

\section{CONCLUSION}

The rosiglitazone systemic administration can lead to cementocytes apoptosis in mice. This finding may help to clarify other unknown relationships between cementocytes and other cell types in the same, neighbor or distant tissues. Despite the significant difference between the control and experimental groups, this study demonstrates the apoptosis in cementocytes as a physiological phenomenon.

\section{REFERENCES}

1. Zhao N, Foster BL, Bonewald LF. The cementocyte - An osteocyte relative? J Dent Res. 2016;95(7):73441, doi:10.1177/0022034516641898.

2. Dallas SF, Prideaux M, Bonewald LF. The osteocyte: an endocrine cell and more. Endocr Rev. 2013 Oct;34(5):658-90, doi: 10.1210/er.2012-1026. 
3. Ponzetti M, Rucci N. Osteoblast differentiation and signaling: established concepts and emerging topics. Int J Mol Sci. 2021 Jun;22(13):6651, doi: 10.3390/ijms22136651.

4. Zhang L, Wen C. Osteocyte dysfunction in joint homeostasis and osteoarthritis. Int J Mol Sci. 2021 Jun;22(12):6522, doi: 10.3390/ijms22126522.

5. Li MCM, Chow SKH, Wong RMY, Qin L, Cheung WH. Type of article: Review article the role of osteocytes-specific molecular mechanism in regulation of mechanotransduction - A systematic review. J Orthop Translat. 2021 May;29:1-9, doi: 10.1016/j.jot.2021.04.005.

6. Li Y, Zhan Q, Bao M, Yi J, Li Y. Biomechanical and biological responses of periodontium in orthodontic tooth movement: up-date in a new decade. Int J Oral Sci. 2021 Jun;13(1):20, doi: 10.1038/s41368-02100125-5.

7. Silva RAB, Sousa-Pereira AP, Lucisano MP, Romualdo PC, Paula-Silva FWG, Consolaro A, et al. Alendronate inhibits osteocyte apoptosis and inflammation via IL-6, inhibiting bone resorption in periapical lesions of ovariectomized rats. Int Endod J. 2020 Jan;53(1):84-96, doi: 10.1111/iej.13206.

8. Lira Dos Santos EJ, Salmon CR, Chavez MB, De Almeida AB, Tan MH, Chu EY, et al. Cementocyte alterations associated with experimentally induced cellular cementum apposition in hyp mice. J Periodontol. 2021 May, doi: 10.1002/JPER.21-0119.

9. Wang H, Li T, Wang X, Yin X, Zhao N, Zou S, et al. The role of sphingosine-1-phosphate signaling pathway in cementocyte mechanotransduction. Biochem Biophys Res Commun. 2020 Mar;523(3):595601, doi: 10.1016/j.bbrc.2020.01.003.

10. Almeida AB, Santos EJLD, Abuna GF, Ribeiro CS, Casati MZ, Ruiz KGS, Nociti Junior FH. Isolation and characterization of a human cementocyte-like cell line, HCY-23. Braz Oral Res. 2019 Aug;33:e058, doi: 10.1590/1807-3107bor-2019.vol33.0058.

11. Soroceanu MA, Miao D, Bai XY, Su H, Goltzman D, Karaplis AC. Rosiglitazone impacts negatively on bone by promoting osteoblast/osteocyte apoptosis. J Endocrinol. 2004 Oct;183(1):203-16, doi: 10.1677/joe.1.05723.

12. Di Paola R, Mazzon E, Maiere D, Zito D, Britti D, De Majo M, et al. Rosiglitazone reduces the evolution of experimental periodontitis in the rat. J Dent Res. 2006 Feb;85(2):156-61, doi: $10.1177 / 154405910608500208$.

13. Hassumi MY, Silva-Filho VJ, Campos-Júnior JC, Vieira SM, Cunha FQ, Alves PM, et al. PPAR-gamma agonist rosiglitazone prevents inflammatory periodontal bone loss by inhibiting osteoclastogenesis. Int Immunopharmacol. 2009 Sep;9(10):1150-8, doi: 10.1016/j.intimp.2009.06.002.

14. Mabilleau G, Mieczkowska A, Edmonds ME. Thiazolidinediones induce osteocyte apoptosis and increase sclerostin expression. Diabet Med. 2010 Aug;(27(8):925-32, doi: 10.1111/j.1464-5491.2010.03048.x.

15. Di Paola R, Briguglio F, Paterniti I, Mazzon E, Oteri G, Militi D, et al. Emerging role of PPAR- $\beta / \delta$ in inflammatory process associated to experimental periodontitis. Mediators Inflamm. 2011 Nov;2011:787159, doi: 10.1155/2011/787159.

16. Silva RAB, Sousa-Pereira AP, Lucisano MP, Romualdo PC, Paula-Silva FWG, Consolaro A, Silva LAB, Nelson-Filho P. Alendronate inhibits osteocyte apoptosis and inflammation via IL-6, inhibiting bone resorption in periapical lesions of ovariectomized rats. Int Endod J. 2020 Jan;53(1):84-96, doi: 10.1111/iej.13206.

17. Matsuzawa H, Toriya N, Nakao Y, Konno-Nagasaka M, Arakawa T, Okayama M, Mizoguchi I. Cementocyte cell death occurs in rat cellular cementum during orthodontic tooth movement. Angle Orthod. 2017 May;87(3):416-22, doi: 10.2319/071116-541.1.

18. Da Silva RA, Ferreira PD, De Rossi A, Nelson-Filho P, Silva LA. Toll-like receptor 2 knockout mice showed increased periapical lesion size and osteoclast number. J Endod. 2012 Jun;38(6):803-13, doi: 10.1016/j.joen.2012.03.017.

19. De Oliveira KM, Da Silva RA, De Rossi A, Fukada SY, Feres M, Nelson-Filho P, et al. Absence of interleukin 22 affects the oral microbiota and the progression of induced periapical lesions in murine teeth. Int Endod J. 2015 Jan;48(1):46-59, doi: 10.1111/iej.12274.

20. Cerri PS, Freymuller E, Katchburian E. Apoptosis in the early developing periodontium of rat molars. Anat Rec. 2000 Feb;258(2):136-44, doi: 10.1002/(SICI)1097-0185(20000201)258:2<136::AIDAR3 >3.0.CO;2-L.

21. Moin S, Kalajzic Z, Utreja A, Nihara J, Wadhwa S, Uribe F, et al. Osteocyte death during orthodontic tooth movement in mice. Angle Orthod. 2014 Nov;84(6):1086-92, doi: 10.2319/110713-813.1.

22. Gavrieli Y, Sherman Y, Ben-Sasson SA. Identification of programmed cell death in situ via specific labeling of nuclear DNA fragmentation. J Cell Biol. 1992 Nov;119(3):493-501, doi: 10.1083/jcb.119.3.493.

23. Chiu CH, Chou YC, Lin JP, Kou CL, Lu HF, Huang YP, et al. Chloroform extract of solanum lyratum induced $\mathrm{G} 0 / \mathrm{G} 1$ arrest via p21/p16 and induced apoptosis via reactive oxygen species, caspases and 
mitochondrial pathways in human oral cancer cell lines. Am J Chin Med. 2015 Oct;43(7):1453-69, doi: 10.1142/S0192415X15500822.

24. Chu F, Xu X, Li G, Gu S, Xu K, Gong Y, et al. Amino acid derivatives of ligustrazine-oleanolic acid as new cytotoxic agents. Molecules. 2014 Nov;19(11):18215-31, doi: 10.3390/molecules191118215.

25. Lecka-Czernik B, Gubrij I, Moerman EJ, Kajkenova O, Lipschitz DA, Manolagas SC, et al. Inhibition of Osf2/Cbfa1 expression and terminal osteoblast differentiation by PPARgamma2. J Cell Biochem. 1999 Sep;74(3):357-71.

26. Lecka-Czernik B, Moerman EJ, Grant DF, Lehmann JM, Manolagas SC, Jilka RL. Divergent effects of selective peroxisome proliferator-activated receptor-gamma 2 ligands on adipocyte versus osteoblast differentiation. Endocrinology. 2002 Jun;27(8):2376-84, doi: endo.143.6.8834.

27. De Oliveira KMH, Garlet GP, De Rossi A, Barreiros D, Queiroz AM, da Silva LAB,Nelson-Filho P, da Silva RAB. Effects of rosiglitazone on the outcome of experimental periapical lesions in mice. J Endod. 2017 Dec;43(12):2061-9, doi: 10.1016/j.joen.2017.06.026.

28. Daniel B, Decoster MA. Quantification of sPLA2-induced early and late apoptosis changes in neuronal cell cultures using combined TUNEL and DAPI staining. Brain Res Brain Res Protoc. 2004 Aug;13(3):144-50, doi: 10.1016/j.brainresprot.2004.04.001.

29. Tang HL, Wang ZG, Li Q, Ran HT, Zheng YY, Ren JL, et al. Targeted delivery of bone mesenchymal stem cells by ultrasound destruction of microbubbles promotes kidney recovery in acute kidney injury. Ultrasound Med Biol. 2012 Apr;38(4):661-9, doi: 10.1016/j.ultrasmedbio.2012.01.003.

30. Searle J, Collins DJ, Harmon B, Kerr JF. The spontaneous occurrence of apoptosis in squamous carcinomas of the uterine cervix. Pathology. 1973 Apr;5(2):163-9, doi: 10.3109/00313027309060831.

31. Bassett JHD, Williams GR. Role of thyroid hormones in skeletal development and bone maintenance. Endocr Rev. 2016 Apr;37(2):135-87, doi: 10.1210/er.2015-1106.

32. Brochado Martins JF, Rodrigues CFD, Nunes PD, Paulo S, Palma PJ, Do Vale FF. Remodelling compartment in root cementum. Folia Morphol (Warsz). 2020 Nov, doi: 10.5603/FM.a2020.0134.

33. Lebovitz HE. Thiazolidinediones: the forgotten diabetes medications. Curr Diab Rep. 2019 Nov 27;19(12):151, doi: 10.1007/s11892-019-1270-y.

34. Wang S, Dougherty EJ, Danner RL. PPAR $\gamma$ signaling and emerging opportunities for improved therapeutics. Pharmacol Res. 2016 Sep;111:76-85, doi: 10.1016/j.phrs.2016.02.028.

35. Stechschulte LA, Czernik PJ, Rotter ZC, Tausif FN, Corzo CA, Marciano DP, et al. PPARG posttranslational modifications regulate bone formation and bone resorption. EBioMedicine. 2016 Aug;10:174-84, doi: 10.1016/j.ebiom.2016.06.040.

36. Cho ES, Kim MK, Son YO, Lee KS, Park SM, Lee JC. The effects of rosiglitazone on osteoblastic differentiation, osteoclast formation and bone resorption. Mol Cells. 2012 Feb;33(2):173-81, doi: $10.1007 / \mathrm{s} 10059-012-2240-\mathrm{z}$. 